\title{
Yazı Biçimi Öğretimi Konusunda Birinci Sınıf Öğretmenlerinin Görüşleri
}

\begin{tabular}{lccc}
\hline MAKALE TÜRÜ & Başvuru Tarihi & Kabul Tarihi & Yayın Tarihi \\
Araştırma Makalesi & 04.12 .2018 & 29.04 .2019 & 29.04 .2019 \\
\hline
\end{tabular}

Yusuf Özdemir iD ${ }^{1}$

Milli Eğitim Bakanlı̆̆

Kasım Kıroğlu

Ondokuz Mayıs Üniversitesi

Öz

2005-2006 öğretim y1lında öğretimine başlanan bitişik eğik yazı, 2017-2018 öğretim yılında yerini dik temel yazıya bırakmıştır. Kullanıldığı süre içinde bitişik eğik yazının birçok açıdan eleştirildiği görülmüştür. Öğrencilerin yazısının okunamaması, bitişik eğik yazı kullanımının ilkokuldan sonra devam etmemesi, günlük yaşamda bu yazı biçimi ile yazılan metin sayısının az olması gibi nedenler bitişik eğik yazının eleştirilen yönleri olmuştur. Bu araştırmada 20172018 öğretim yılında birinci sınıf okutan ayrıca daha önce birinci sınıfta bitişik eğik yazı öğretimi yapmış sınıf öğretmenlerinin dik temel yazıya ve bitişik eğik yazıya ilişkin görüşlerinin karşılaştırmalı olarak ortaya koyulması amaçlanmıştır. Bu amaçla Samsun iline bağlı Alaçam ilçesindeki sınıf öğretmenleri ile görüşmeler yapılmıştır. Araştırmanın çalışma grubunu daha önce bitişik eğik yazı öğretimi de yapmış bütün birinci sınıf öğretmenleri oluşturmaktadır. Araştırmada nitel araştırma yöntemlerinden durum çalışması kullanılmıştır. Araştırma verileri araştırmacılarca geliştirilen yarı yapılandırılmış görüşme formu ile toplanmıştır. Elde edilen veriler üzerinden betimsel analiz yapılmıştır. Araştırma sonucunda çalışma grubundaki öğretmenlerin birinci sınıf öğrencilerine dik temel yazı öğretimini olumlu karşılarken bitişik eğik yazı öğretimini olumsuz karşıladıkları görülmüştür. Dik temel yazı ile ilgili olarak harflerin yazım şekli ve harfin bulunduğu grup ile ilgili bazı sorunların bulunduğu ifade edilmiştir. Bitişik eğik yazı öğretiminde ise hazırbulunuşluk, yazıyı ortaokulda kullanma ve yazıya maruz kalma konularında sorunlarla karşılaştıklarını belirtmişlerdir.

Anahtar sözcükler: Dil becerileri, yazma, yazı öğretimi, bitişik eğik yazı, dik temel yazı.

${ }^{1}$ Sorumlu Yazar: Dr., Şehit Muhammet Ali Aksu İlkokulu, Alaçam-Samsun, E-posta: yusuefozdemir@hotmail.com, https://orcid.org/0000-0003-2024-6916

${ }^{2}$ Doç. Dr., Eğitim Fakültesi, Temel Eğitim Bölümü, Sınıf Eğitimi Anabilim Dalı, E-posta: november@omu.edu.tr, https://orcid.org/0000-0001-5711-9182 
Yazma eylemi, insanlar arasındaki yazılı iletişimin bir gereği ve bilgilerin, yaşantıların kalıcı olmasının önemli bir yoludur. İnsan tarafından üretilen düşünce, yazarak dış dünyaya aktarılabilmekte ve kalıcı olabilmektedir (Coşkun ve Coşkun, 2012). Yazma, duygu ve düşünceleri özel semboller aracılığı ile anlatma işlemidir (Güneş, 2007). Bireyin duygu ve düşüncelerini çevresiyle paylaşabilmesi etkin bir yazma becerisinin kazanılmasına bağlıdır (Kırmızı ve Kasap, 2013). Yazma eyleminde kullanılan seslere, kelimelere ya da cümlelere karşılık gelen sembollere yazı denmektedir. Çelenk (2007) yazıyı konuşma dilindeki sözcük ve cümlelerin sembolik çizimlerle dışa aktarılması olarak tanımlamaktadır. Yazı insanların bilgilerini, düşüncelerini ve duygularını yazılı olarak anlatmasını sağlayan, insanlık tarihinin en önemli buluşlarından biridir.

Bireyin yazma eylemini gerçekleştirmesi, yazı yazmasını öğrenmesine bağlıdır. $\mathrm{Bu}$ nedenle yazı öğretimi eğitim programları için önemli bir konudur. İlkokul birinci sınıftan başlayarak okuma öğretimi ile yazı öğretimi de gerçekleştirilmektedir. İşlek ve estetik bir yazı öğretiminin temeli ilkokuma-yazma öğretimi ile atılmaktadır (Coşkun ve Coşkun, 2012; Duran ve Akyol, 2010; Güneş, 2017). Türkçe öğretim programı ile amaçlanan öğrencilerin kendilerine has, göze hoş gelen, seri, işlek ve akıcı bir el yazısı yazmalarıdır (Milli Eğitim Bakanlığı-MEB, 2018).

Yazı öğretimi sürecini etkileyen öğelerden biri kullanılan yazı biçimidir (Arslan, 2012). İşlek ve akıcı el yazısı için farklı yazı biçimlerinin etkiliği yıllardır tartışılmaktadır (Graham, 2010; Güneş, 2017). Bu anlamda ön plana çıkan iki yazı biçimi; dik temel yazı ve bitişik eğik yazıdır. Bu yazı biçimleri kendilerine özgü farklı özellikler içermektedir. Dik temel yazı, her harfin düz ve sade çizgilerle 90 derecelik açı ile yazıldığı bir yazı şeklidir (Güneş, 2017). Bu yazı biçiminde daha çok kısa ve kesik çizgiler kullanılır (Kırmızı ve Kasap, 2013). Kısa ve kesik çizgiler nedeni ile el sıkça kaldırılmaktadır (Güneş, 2017). Bu nedenle harfler arasında uygun boşlukların bırakılması gerekir (Duran ve Akyol, 2010). Bu harfleri yazmak için altı hareket yapılmaktadır (Akyol, 2005). Ayrıca harflerin yazımı dokuz farklı noktadan başlamaktadır. Bu durum öğrencilerin kelimeleri yazarken sürekli durmalarına ve durdukları yerden başka bir yerde yazmaya başlamalarına neden olmaktadır. Bu durum yazma hızını olumsuz olarak etkilemektedir (Şahin, 2012). Ancak dik temel yazı sadeleştirilmiş biçimi ve erken yazılı anlatıma firsat vermesi yönü ile tercih edilen bir yazı şeklidir. Ayrıca önemli belgelerde ve farklı görsel sunularda (harita, grafik, tabela vb.) kullanılması bu yazı biçiminin önemini ortaya koymaktadır (Sharp ve Brown, 2015).

Bir diğer yazı biçimi olan bitişik eğik yazıda harfler belli bir eğimde birbirine bitiştirilerek yazılmaktadır. Bu yazı biçiminde el çok fazla kalkmamakta ve harfler yazılırken üç farklı hareket yapılması gerekmektedir (Akyol, 2005). Öğrenci elini kaldırmadan kelimeyi yazmakta ve sonrasında gerekli ise kelimenin nokta ya da kısa çizgilerini koymaktadır. Yazarken daha çok yuvarlak çizgilerden yararlanılmaktadır. Bitişik eğik yazının sürekli, akıcı ve hızlı olması öğrencinin düşüncesini unutmadan hızlı bir şekilde aktarmasını sağlamaktadır (Şahin, 2012). 
Dik temel yazı ve bitişik eğik yazı kullanımı ile ilgili dünyada kabul gören tek bir görüş olmadığı görülmektedir. Ancak dünyadaki gelişmeler izlendiğinde son yıllarda dik temel yazının öğretildiği görülmektedir (Güneş, 2017). Örneğin ABD’de birinci sınıfta yazı biçimi olarak dik temel yazı tercih edilmekte, ikinci ve üçüncü sınıftan itibaren bitişik eğik yazı öğretilmektedir (Yıldız, 2019). Yine 1998 Kanada dil programında bitişik eğik yazı öğretiminin üçüncü sınıfta başladığı belirtilmektedir (Prince Edward Island Department of Education and Early Childhood Development Holman Centre-EECD, 2012). 1981 Türkçe programında öğrencilere dik temel yazı öğretilmekte, bitişik eğik yazının öğretimine ise ikinci sınıftan itibaren başlanmaktadır (Kırmızı ve Kasap, 2013). 2005 yılından itibaren ise öğrencilere birinci sınıfta bitişik eğik yazı öğretimi yapılmaya başlanmıştır. 2017-2018 öğretim yılında ise bu uygulama kaldırılmış, yazı biçimi seçimi serbest bırakılmıştır. Özellikle bitişik eğik yazının kullanıldığı sürede hangi yazı biçimi öğretiminin gerçekleştirileceği ile ilgili tartışmalar yoğun biçimde sürdürülmüştür. $\mathrm{Bu}$ tartışmalarda her iki yazı biçimi birbiri ile sıkça karşılaştırılmıştır. Ancak hangi yazı biçiminin daha etkili olduğu ile ilgili olarak açıklayıcı bir araştırma bulunmamaktadır (Graham, 2010).

İki yazı biçimi birbiri ile el hareketleri yönünden karşılaştırıldığında bitişik eğik yazıda daha az başlangıç noktası olduğu ve elin yazı yazarken çok fazla kalkmadığı görülmektedir (Bara ve Morin, 2013). Bu durum bitişik eğik yazının daha akıcı yazmaya zemin hazırladığı biçiminde yorumlanabilmektedir. Ayrıca elin kalkmamasından dolayı harflerin boyları ve aralarındaki mesafeyi ayarlamak için çok fazla çaba harcanmasına gerek kalmamaktadır. Dik temel yazıda el çok fazla kalktığı için harfler arasında boşluklar ayarlanırken zorlanılmaktadır. Bu sayılan noktalar bitişik eğik yazının üstünlükleri olarak görülmektedir.

Çocuklar küçük yaştan itibaren gördükleri yazıları taklit ederek yazı yazmayı kendi kendilerine öğrenmeye çalışmaktadırlar (Yıldız, Ataş, Aktaş, Yekeler ve Dönmez, 2015). Gördükleri yazılar çoğunlukla dik yazılardır. Bu nedenle öğrenciler okula geldiklerinde belli bir el alışkanlığı ile gelmektedirler ve belli başlı dik harfleri yazabilmektedirler. $\mathrm{Bu}$ durum öğrencilerin dik temel yazıyı öğrenmeleri için bir üstünlük oluşturmaktadır. Ayrıca hem basılı hem de dijital yayınlarda sıklıkla bu harflerle karşılaşacaklardır. Bu durum dik temel yazıya yatkınlığı daha çok arttırmaktadır (Graham, 2010; Sharp ve Brown, 2015).

Öğrencilerin okunabilir ve belli bir hızda el yazısı yazabilmeleri onların düşüncelerini yazıya geçirmeleri için oldukça önemlidir. Yazma hızı öğrencilerin zihinlerindeki fikirleri unutmadan yazmaları için oldukça önemlidir (Graham ve Weintraub, 1996). Öğrenciler okulda not almak, yazılı metin üretmek ya da sınav sorularını cevaplamak gibi akademik görevlerle karşı karşıyadırlar. Bu nedenle el yazısı öğrencilerin başarısını güçlü biçimde etkilemektedir (Sharp ve Brown, 2015).

Son zamanlarda yapılan çalışmalar el yazısı, yazım ve metin üretimi arasında ilişki olduğunu ortaya koymaktadır (Christensen, 2005). Metin üretimi çoğunlukla bilişsel ve üstbilişsel yeteneklerin bir eşgüdümü olarak görülmekte, yazma sırasında 
kullanılan el yazısı becerilerinin bu süreçte daha az öneme sahip olduğu düşünülmekteydi. Ancak bazı çalışmalar el yazısının düşünüldüğünden daha fazla öneme sahip olduğunu belirtmektedir. Öyle ki yaratıcı ve iyi yapılandırılııs metinler üretmek için öğrencilerin harfleri, kelimeleri ve cümleleri otomatikleşmiş biçimde sayfaya yerleştirmelerini sağlayan mekanik becerilerde usta olmaları gerekmektedir (Morin, Lavoie ve Montesinos, 2012). Eğer el yazısı otomatik değilse yazmak için gerekli olan bilişsel yük zihinde karmaşık bilişsel etkinliklerin yapılmasını engelleyebilir (Christensen, 2005 akt. Morin, Lavoie ve Montesinos, 2012). Eğer öğrenciler yavaş yazarlarsa fikirlerini yazmadan önce hatırlamada zorluk çekeceklerdir (Graham ve Weintraub, 1996). Bu nedenle bazı çalışmalar daha kolay öğrenilmesinden, daha okunaklı olmasından ve en az bitişik eğik yazı kadar hızlı üretilebilir olmasından dolayı düşük düzeylerde dik temel yazı öğretimini desteklemektedir (Wallace ve Schomar, 1994 akt. Sharp ve Brown, 2015).

Duval'e (1985) göre bitişik eğik yazı daha zordur. Dik temel yazı öğrencilerin algisal ve motor becerilerine daha fazla uymakta ve bu nedenle daha kolay yönetilebilmektedir (akt. Bara ve Morin, 2013). Yüksek eğrilikli ve ani eğrilik değişimleri olan harfler, motor eylem açısından zordur. Meulenbroek ve van Galen (1990), 2. ve 6. sınıf çocukları ile yaptıkları çalışmada daha büyük çocukların hafif kavisli çizgiler kullanarak el yazısı harfleri oluşturduğunu, kü̧̈ük çocukların ise düz çizgiler kullandıklarını gözlemlemişlerdir. Bu durum özellikle küçük yaşlarda dik temel yazı kullanımının daha uygun olduğu biçiminde yorumlanabilir.

Dik temel yazı aynı zamanda harf şekillerinin kararlılı̆̆ı ve diğer harflerden etkilenmemesi nedeni ile de kolay görülmektedir. Ayrıca, yazımındaki sayısız kalem kaldırılması, çocukların sonraki hareketi daha iyi planlayabilmeleri için zaman ayırmalarını sağlamaktadır (Meulenbroek ve van Galen, 1986). Ancak dik temel yazıdaki basit şekiller ve çok sayıdaki simetrik harfler, harfler arasındaki farklılı̆̆ bitişik eğik yazıya göre daha zor yapar (Paoletti, 1999 akt. Bara ve Morin, 2013).

Berninger ve diğ. (2006), dik temel yazı, bitişik eğik yazı ve klavye harflerinin üretilmesindeki gelişimsel yörüngeleri ve bu yazılı üretim biçimlerinin yordayıcılarını araştırmışlardır. Sonuçlar, bitişik eğik yazının dik ve klavye yazısına göre daha az doğru ve daha yavaş olduğunu göstermiştir. Bitişik eğik yazı, dik temel yazı ve klavye yazısı arasında sadece orta derecede bir iliş̧i bulunmuş ve her bir yazı biçiminin farklı bir belirleyici kümesi olduğu ortaya konmuştur (Bara ve Morin, 2013). Graham, Weintraub ve Berninger (1998), el yazısı biçiminin okunabilirlik ve yazma hızı üzerindeki etkisini inceledikleri araştırmada bitişik eğik yazı ile dik temel yazıyı bütünleştiren öğrencilerin sadece bir biçim ile yazan öğrencilerden daha hızlı yazdıklarını ortaya koymuşlardır. Ayrıca dik temel yazı ile bitişik eğik yazı arasında okunabilirlik ve hız bakımından bir fark bulamamışlardır.

Alanyazında dik temel yazı ve bitişik eğik yazı öğretimi ile ilgili birçok çalışma yer almaktadır. Yurt dışında yirminci yüzyıl ile başlayan bu çalışmalar (Gates ve Brown, 1929) Türkiye'de 2005 yılında bitişik eğik yazının öğretilmeye başlanmasıyla bir artış göstermiştir. Bu yıldan sonra yapılan çalışmalarda ise farklı sonuçlara 
rastlanmıştır. Kimi çalışmalarda bitişik eğik yazı kullanımı olumlu karşılanırken (Durukan ve Alver, 2008; Turan ve Akpınar, 2008) kimi çalışmalarda olumsuz (Bayraktar, 2006; Kırmızı ve Kasap, 2013; Yurduseven, 2007) olarak değerlendirilmiştir. Bu çalışmaların daha çok bitişik eğik yazının kullanımına yönelik gerçekleştirildiği söylenebilir. Türkiye'de 2017-2018 öğretim yılı ile birlikte bitişik eğik yazı öğretimi bir zorunluluk olmaktan çıkarılmış ve yazı biçiminin seçimi öğretmenlere bırakılmıştır. Bu anlamda her iki yazı biçiminin öğretimine yönelik durumu ortaya koyabilmek için hem bitişik eğik yazı hem de dik temel yazı öğretimi yapmış sınıf öğretmenlerinin iki yazı biçimi ile ilgili görüşlerini almak oldukça önemlidir. Bu karşılaştırmanın yapıldı̆̆ 1 farklı çalışmalara rastlanmıştır. Kırmızı ve Kasap (2013), bitişik eğik yazı öğretimi sürecinde her iki yazı biçimi ile ilgili 1. ve 2. sınıf öğretmenlerinin görüşlerini almıştır. Çakır, Aslantaş Arslan ve Doğan (2018) ise yine bitişik eğik yazı öğretimi sürecinde sınıf öğretmenlerinin her iki yazı biçimi hakkında görüşlerini değerlendirmiştir. Bu çalışma ise her iki yazı biçimi ile okumayazma öğretmiş ve dik temel yazı öğretimine geçildiğinde birinci sınıfta görev yapmakta olan sınıf öğretmenlerinin bu yazı biçimlerine ilişkin görüşlerini ortaya koyması bakımından diğer araştırmalardan farklılaşmaktadır. Özellikle dik temel yazı öğretimine yeni başlanması, bitişik eğik yazı kullanımının yeni sonlandırılmış olması öğretmenlerin iki yazı biçimi ile ilgili düşüncelerinin net bir şekilde ortaya konulabilmesi için uygun bir zaman olarak görülmektedir. Bu nedenle araştırmanın önemli olduğu düşünülmektedir.

Sınıf öğretmenleri yazı öğretimi sürecinde etkin biçimde yer almaktadırlar. Özellikle birinci sınıfta yazı öğretimine oldukça önem vermektedirler. Sınıfta öğrenciler ile birlikte yapılan çalışmalar onların yazı öğretimi ile ilgili çok fazla deneyime sahip olmalarını sağlamaktadır. Bu araştırmada öğretmenlerin bu deneyimlerinden yararlanılarak onların yazı biçimlerine yönelik düşüncelerinin ortaya çıkarılması amaçlanmıştır. Araştırmada, hem daha önce bitişik eğik yazı ile okuma-yazma öğretimi gerçekleştirmiş hem de 2017-2018 öğretim yılında dik temel yazı ile birinci sınıfta okuma-yazma öğretimi yapan sınıf öğretmenlerinin her iki yazı biçimi ile ilgili düşüncelerini ayrıntılı olarak ortaya koymak amaçlanmıştır. Bu amaç doğrultusunda araştırmada aşağıdaki problemlere çözümler aranmıştır.

1. Sınıf öğretmenlerinin bitişik eğik yazıya ilişkin düşünceleri nelerdir?

2. Sınıf öğretmenlerinin dik temel yazıya ilişkin düşünceleri nelerdir?

3. Sınıf öğretmenlerinin el yazısı biçiminin okuma sürecine olan etkisine yönelik düşünceleri nelerdir?

4. Sınıf öğretmenlerinin bitişik eğik yazının öğretilmesine ilişkin görüşleri nelerdir? 


\section{Yöntem}

$\mathrm{Bu}$ bölümde araştırmanın modeli, çalışma grubu, veri toplama araçları, veri toplama yöntemi, geçerlik ve güvenirliği, veri analizi ile ilgili ayrıntılı bilgiler sunulmuştur.

\section{Araştırma Modeli}

Araştırmada nitel araştırma yöntemlerinden durum çalışması kullanılmıştır. Durum çalışması gerçek yaşamın, güncel bağlamın ya da ortamın içerisindeki bir durumun araştırılması olarak tanımlanmaktadır. Araştırmacı, sınırlarıyla birlikte açıkça tanımlanabilir durumlara sahip olduğunda ve bu durumla ilgili derinlemesine bir anlayış oluşturmaya çalıştığında durum çalışması iyi bir yaklaşımdır (Creswell, 2016). Bu çalışmada iki yazı biçimi ile ilgili öğretmen görüşlerinin derinlemesine incelenerek ortaya konulması amaçlanmaktadır. Araştırılacak durumun açıkça ortaya konulması ve derinlemesine bir araştırmaya gereksinim duyulmasından dolayı bu çalışmada durum çalışması tercih edilmiştir. Durum çalışmalarında genel olarak niçin ve nasıl sorularına yanıt aranmaktadır. Bu soruların yanı sıra ne sorusu da gereklidir (Yıldırım ve Şimşek, 2013). Araştırmada yazı biçimleri ile ilgili sınıf öğretmenlerinin yazı biçimlerini nasıl değerlendirdiklerinin, niçin bir yazı biçimini seçtiklerinin cevabı bulunmaya çalışılmaktadır.

\section{Çalıșma Grubu}

Araştırmanın çalışma grubunu Samsun ilinin Alaçam ilçesinde görev yapan daha önce bitişik eğik yazı ile okuma-yazma öğretimi gerçekleştirmiş, 2017-2018 öğretim yılında dik temel yazı ile okuma yazma öğreten bütün birinci sınıf öğretmenleri oluşturmaktadır. Çalışma grubu belirlenirken hem bitişik eğik yazının hem de dik temel yazının öğretimini gerçekleştirmiş öğretmenlerin seçilmesindeki neden, iki yazı biçimi ile ilgili olumlu ya da olumsuz görüşlerin ortaya konulabilmesidir. Çalışma grubu ile ilgili bilgiler Tablo 1'de sunulmaktadır.

\section{Tablo 1}

Çalışma Grubunda Yer Alan Sınıf Öğretmenlerinin Özellikleri

\begin{tabular}{llll}
\hline Kod & Kıdem & Çalıştı̆̆ Okul & Veri Toplanma Şekli \\
\hline Ö1E & 23 & Taşımalı İlkokul & Yüzyüze \\
\hline Ö2K & 19 & Taşımalı İlkokul & Yüzyüze \\
\hline Ö3K & 27 & Merkezi İlkokul & Yüzyüze \\
\hline Ö4E & 36 & Merkezi İlkokul & Yüzyüze \\
\hline Ö5K & 25 & Merkezi İlkokul & Yazılı \\
\hline Ö6E & 22 & Merkezi İlkokul & Yazılı \\
\hline Ö7K & 24 & Taşımalı İlkokul & Yazılı \\
\hline Ö8E & 30 & Merkezi İlkokul & Yüzyüze \\
\hline Ö9K & 32 & Merkezi İlkokul & Yazılı \\
\hline Ö10K & 6 & Taşımalı İlkokul & Yazılı
\end{tabular}


Tablo 1 (devam)

\begin{tabular}{llll}
\hline Kod & Kıdem & Calıştı̆̆ı Okul & Veri Toplanma Şekli \\
\hline Ö11E & 8 & Taşımalı İlkokul & Yüzyüze \\
\hline Ö12E & 15 & Merkezi İlkokul & Yüzyüze \\
\hline Ö13K & 30 & Merkezi İlkokul & Yazılı \\
\hline Ö14K & 24 & Taşımalı İlkokul & Yüzyüze \\
\hline Ö15E & 26 & Merkezi İlkokul & Yazılı \\
\hline Ö16E & 12 & Taşımalı İlkokul & Yazılı \\
\hline
\end{tabular}

Çalışma grubu 8 kadın ve 8 erkek olmak üzere 16 sınıf öğretmeninden oluşmaktadır. Araştırmanın birinci yazarı 2017-2018 öğretim yılında ilçe birinci sınıflar zümre başkanlığını yürütmüş, bu nedenle zümresinde yer alan ve araştırmanın çalışma grubunu oluşturan on altı öğretmen ile sürekli iletişim kurmuştur. Ancak bu öğretmenlerden 8'i ile yüz yüze görüşme gerçekleştirilebilmiştir. Diğer öğretmenlerin görüşleri ise yazılı olarak alınmıştır.

\section{Veri Toplama Araçları}

Araştırmada veri toplama aracı olarak yarı yapılandırılmış görüşme formu kullanılmıştır. Yarı yapılandırılmış görüşme formunu araştırmacılar geliştirmiştir. Görüşme formu oluşturulurken öncelikle dik temel yazı ve bitişik eğik yazı ile ilgili yapılan çalışmalar incelenmiştir. Daha sonra on iki açık uçlu soru belirlenmiştir. Bu sorular ile daha önce bitişik eğik yazı öğretimi yapmış iki sınıf öğretmeni ile görüşme yapılmıştır. Görüşme sonucunda bazı sorular çıkarılarak yarı yapılandırılmış görüşme formuna son biçimi verilmiştir.

Yarı yapılandırılmış görüşme formundaki sorular tekrar gözden geçirilerek sınıf öğretmenlerin yazılı olarak cevaplayabileceği duruma getirilmiştir. Hazırlanan açık uçlu sorular sınıf öğretmenlerine gönderilmiştir. Sınıf öğretmenlerinden yazılı olarak soruları yanıtlamaları istenmiştir.

Dik temel yazı ve bitişik eğik yazının kullanımına yönelik sınıf öğretmenlerinin genel olarak düşüncelerinin neler olduğunun belirlenebilmesi için zümre öğretmen toplantılarında öğretmen görüşleri dinlenilmiştir. Burada elde edilen önemli bilgiler not edilmiştir. Yine birinci yazar tarafından yürütülen ilkokuma-yazma öğretimi sürecinde öğrencilerin dik temel yazı kullanımı ile ilgili gözlemler yapılmıştır.

Araştırmada kullanılan veriler hem yüzyüze görüşülerek hem de yazılı olarak toplanmıştır. Her iki veri toplama yönteminin kendi içinde üstünlükleri ve sınırlılıkları bulunmaktadır. Görüşme yöntemi özellikle ulaşılabilir sınıf öğretmenleri ile yürütülmüştür. $\mathrm{Bu}$ şekilde ulaşılabilir olan sekiz öğretmenle yüz yüze görüşmeler gerçekleştirilmiştir. Görüşmeler öğle arasında ya da okul çıkışında yapılmıştır. Yapılan görüşmelerin süresi yirmi dakika ile otuz dakika arasında değişim göstermiştir. Yüzyüze görüşme olanağı bulunamayan öğretmenlerden yarı yapılandırılmış görüşme formundan hareketle hazırlanmış soruları yazılı olarak cevaplamaları istenmiştir. 


\section{Araștırmanın Geçerlik ve Güvenirliği}

Nitel araştırmaların belli bir felsefi dayanağı ve özel amaçları olduğundan dolayı nitelik ve inanırlıklarını yargılamak için farklı ölçütler geliştirilmektedir (Patton, 2014). Lincoln ve Guba (1985) doğal araştırmaya daha sadık olduğunu iddia ettikleri kavramlar ortaya koymuşlardır (Creswell, 2016). Bu kavramlar iç geçerliğe benzer olarak inandırıcılık; dış geçerliğe benzer olarak aktarılabilirlik; tutarlığa benzer olarak güvenebilirlik; nesnelliğe benzer olarak onaylanabilirliktir (Patton, 2014; Creswell, 2016).

İnandırıcılık, nitel araştırmalarda genellikle içsel geçerlik terimi yerine kullanılmaktadır. İnandırıcılık bulguların gerçeklikle ne derecede uyumlu olduğunu göstermektedir (Arastaman, Öztürk Fidan ve Fidan, 2018). Araştırmacıların elde ettiği verilerin ve ulaştıkları sonuçların inandırıcılığını ortaya koyacak stratejileri uygulaması gerekmektedir (Yıldırım, 2010). Bu yöntemlerden bazıları; iyi bilinen yöntemlerin kullanılması, uzun süreli etkileşim kurulması, sürekli gözlem yapılması, farklı veri kaynaklarından yararlanılması, katılımcı denetiminin sağlanması, araştırmacının ön yaşantılarının yeterli olması ve önceki araştırma sonuçlarıyla karşılaştırılmasıdır (Yıldırım, 2010; Başkale, 2016; Arastaman ve dĭğ., 2018).

Birinci yazar görevi gereği 2017-2018 öğretim yılında birinci sınıfı okutmuştur. $\mathrm{Bu}$ durum araştırmanın inandırıcılığı için oldukça önemlidir. Araştırmacının araştırmanın konusuyla ilgili doğrudan yaşantılara sahip olduğunu göstermektedir. $\mathrm{Bu}$ süreçte hem sınıfta öğrencileri ile hem de meslektaşları ile sürekli etkileşim kurmuştur. Bu etkileşim hem derinlemesine bilgi toplamak hem de elde edilen bulguların paylaşılması için oldukça önemlidir.

Aktarılabilirlik, pozitivizmdeki dışsal geçerliğin istediği bulguların genellenebilirliğinin nitel çalışmalardaki karşılığıdır. Araştırma bulgularının benzer durum ve bağlamlara ne derecede uygun olduğu ile ilgilidir. Bulguların aktarılabilirliğinin sağlanması için örneklem seçiminde izlenen yolun ve araştırmaya etki eden bağlamsal etmenlerin iyi betimlenmesi gerekmektedir (Arastaman ve diğ., 2018). Bu araştırmanın çalışma grubu bir ilçede görev yapan bütün birinci sınıf öğretmenlerini içermektedir. Sınıf öğretmenlerinin bir kısmı merkezi okullarda, bir kısmı taşımalı okullarda çalışmaktadırlar. Çalışma grubundaki öğretmenlerin kıdemleri 6 yıl ile 36 yıl arasında değişmektedir. Çalışma grubu yalnız birinci sınıf öğretmenlerinden oluşturulmuştur. Çünkü bu öğretmenler yeni uygulamaya konulan dik temel yazı öğretimini gerçekleştirmektedirler. $\mathrm{Bu}$ açıdan bakıldığında araştırmanın çalışma grubunun araştırmanın bulgularının aktarılabilmesi için uygun olduğu söylenebilir.

Güvenebilirlik, araştırma bulgularının ve yorumlarının tutarlı bir sürecin ürünü olmasını belirtmektedir (Arastaman ve diğ., 2018). Bu nedenle araştırma sürecinin ayrıntılı olarak ortaya konması gerekmektedir. Araştırmanın ortaya çıkış noktası bitişik eğik yazı öğretiminden dik temel yazı öğretimine geçiş sürecidir. Bu geçiş sürecinin iki yazı biçiminin karşılaştırılması için uygun bir dönem olduğu düşünülüp 
her iki yazı biçimini öğreten öğretmenlerin görüşleri alınmıştır. Öncelikle bitişik eğik yazı öğretim sürecinde sınıf öğretmenleri ile planlı olmayan görüşmeler yapılmıştır. Ayrıca alanyazında yapılmış araştırmalar incelenmiştir. Bu görüşmeler ve incelemeler sonucunda elde edilen görüşlerden hareketle bazı önemli noktalar belirlenmiştir. Dik temel yazı öğretimine geçildiği için her iki yazı biçimi arasındaki karşılaştırmanın yapılmasında bu önemli noktalar üzerinden hareket edilmiştir. Yine dik temel yazı öğretimi gerçekleştiren öğretmenlerle yapılan toplantılarda öğretmenlerin her iki yazı biçimi ile ilgili görüşleri dinlenmiş, araştırmada kullanılacak veri toplama aracı bu görüşler 1şı̆̆ında ortaya çıkarılmıştır. Sonrasında bazı öğretmenlerden yüzyüze görüşme sırasında, bazı öğretmenlerden ise yazılı olarak düşüncelerini belirtmeleri istenmiştir. Öğretmenlerden alınan dönütler sonucunda araştırmanın bulgular ve yorumlar bölümleri oluşturulmuştur. Oluşturulan bu bölümler araştırmanın içinde yer almayan iki sınıf öğretmeni ve iki alan uzmanınca değerlendirilmiştir. Sınıf öğretmenleri ve uzmanlardan alınan sonuçlar birbiri ile paralellik göstermiş ve araştırmanın güvenirliği hakkında olumlu dönütler sağlamıştır.

Onaylanabilirlik, araştırma bulgularının araştırmacı tarafından yorumsuz bir biçimde ortaya konulması ve olabildiği kadar araştırılan durumun yansız biçimde ele alınması ile ilgilidir. Burada amaç elde edilen verilerden ulaşılan sonuca kadar geçen süreci kanıtlarla göstermektir (Başkale, 2016). Bu araştırmada farklı veri kaynakları kullanılmıştır. Araştırmacılar sınıf öğretmenleri ile yüzyüze görüşmeler gerçekleştirmişlerdir. Yine sınıf öğretmenlerinden yazılı olarak görüşleri alınmıştır. Bunun yanında araştırmanın birinci yazarı diğer sınıf öğretmenleri gibi dik temel yazı öğretimi gerçekleştirmiştir. Bu süreçte öğrencilerin dik temel yazıyı yazma durumları ile ilgili gözlemler yapma olanağı bulmuştur. Bunun yanında hem ilçede hem de ilde yapılan zümre toplantılarına katılarak farklı öğretmen görüşlerini dinlemiştir. Araştırmacılarca yapılan bu uygulamalar araştırmacıların elinde pek çok verinin olmasını sağlamıştır. Farklı özellikteki bu veriler araştırmacıların görüşlerinin ve araştırma grubundan elde edilen verilerin birbirini destekler nitelikte ve yansız olmasını sağlamaya yardımcı olmuştur.

\section{Verilerin Analizi}

Araştırmada elde edilen veriler üzerinden betimsel analiz yapılmıștır. Betimsel analizde elde edilen veriler önceden belirlenen temalara göre özetlenmekte ve yorumlanmaktadır (Yıldırım ve Şimşek, 2013). Bu araştırmadan elde edilen veriler araştırmanın problemlerine göre düzenlenmiştir. Elde edilen veriler öncelikle araştırma problemlerine göre gruplanmıştır. Her bir problemin altında gruplanan veriler okunarak anlamlı ve mantıklı bir şekilde bir araya getirilmiştir. Bu şekilde elde edilen bulgular doğrudan alıntılar ile desteklenmiştir.

\section{Bulgular}

$\mathrm{Bu}$ bölümde araştırmanın problemleri teker teker ele alınmıştır. Araştırmadan elde edilen veriler her bir problem başlığı altında detaylı olarak analiz edilmiştir. 


\section{Sınıf Öğretmenlerinin Bitișik Eğik Yazıya İlișkin Düșünceleri}

Araştırmaya katılan sınıf öğretmenlerinin birinci sınıfta bitişik eğik yazının öğretilmesine ilişkin düşüncelerinin olumsuz olduğu görülmektedir. Öğretmenlerin olumsuz düşünmelerinin farklı nedenleri bulunmaktadır. Bu nedenlerden en çok üzerinde durulanı öğrencilerin küçük kas gelişimlerinin bitişik eğik yazı yazmaya uygun olmayışı1ır. Ö1 bu durumu, "Öğrencilerin parmak kasları güçlü olmadığı için bitişik eğik yazıyı yazmada zorlanıyorlardı. Özellikle kırsaldaki öğrenciler için bu daha büyük bir sorundu" biçiminde belirtmiştir. Bitişik eğik yazıda bir kelime yazılırken elin hiç kaldırılmaması öğrencilerin ellerinin yorulmasının bir nedeni olarak görülmektedir. Bu durum öğrencilerin olumsuz duygular geliştirmelerine de neden olmaktadır. Ö12, bitişik eğik yazı yazmada zorlanan öğrencilerin "yapamıyorum, olmuyor, beceremiyorum" gibi olumsuz ifadeler kullandığını belirtmiştir. Bu olumsuz ifadeler öğrencilerin yazmaya ve okula ilişkin tutumlarını olumsuz yönde etkilemektedir.

Öğretmenler bitişik eğik yazının estetik özelliğe sahip olmasının öğrencileri zorladığını belirtmişlerdir. Ö7, bitişik eğik yazının estetik bir yazı olduğunu, bu özelliğinden dolayı öğretiminin bir yıla sıkıştırılmaması gerektiğini belirtmiştir. Bir yılda hem okumanın hem de bitişik eğik yazının öğretilmeye çalışılmasının okumayazma öğretimi sürecinde aceleciliğe neden olduğunu belirtmiştir. Bu konuda, "Amaç çabuk öğretmek yerine doğru öğretmek olmalıydı. Yanlış öğrenilen bilgiler kalıcı oldu. Bu yanlışların düzeltilmesi çok zor oldu ya da düzeltilemedi” diyerek öğretim sürecinde yaşanan olumsuzları belirtmiştir.

Öğrencilerin yazılı kaynaklarda bitişik eğik yazı ile fazla karşılaşmamaları bitişik eğik yazı öğretiminin olumsuz olarak görülmesinin diğer bir nedeni olarak görülmektedir. Ö5, "Çevrelerinde sürekli düz yazı ile karşıllaşmaktalar. Bu genelde birinci sınıfta sıkıntı yaşanmasına neden oluyordu" diyerek öğrencilerin öğrendiklerini pekiştirecek yazılı kaynakların fazla olmadığını ortaya koymaktadır. Ö11'in, "Bitişik eğik yazıyı öğrettikten sonra düz yazı kitaplarının olması, her şeyi düz yazı görmeleri sanki iki kere okuma-yazma eğitimi gibi oluyor" diyerek öğrencilere iki biçimi birlikte öğretmenin zorluğuna vurgu yaptığı görülmektedir.

Öğretmenler bitişik eğik yazıda harfleri tamamlamak için yapılan geri dönüşlerin bir olumsuzluk oluşturduğunu belirtmişlerdir. Ö1bu konuda "El yazısında geri dönüşlerde sıkıntı oluyordu. Öğrenciler tekrar nokta ya da çizgileri koymaları için dönüşler yapıyordu. Bu da bir zorluğa neden oluyordu" demiştir. Yine bir başka zorluk ise harflerin birbirine benzemesi sonucunda oluşmaktadır. Ö4 bu durumu, “ "Şi i r ” kelimesi yazarken "ş i i r "ve "şü r” arasındaki fark anlaşılamıyor. Harflerin yazımından dolayı okumada zorlanılıyor" şeklinde belirtmiş̧ir. Ö3, sadece harfleri yazarken değil, oluşturulan hece ve kelimelerin yazımında da öğrencilerin zorlandıklarını belirtmiştir. "Bitişik eğik yazı hamle olarak zorluklar içeriyor. Hamleleri kavraması, onu öğrenip belli sırayla eyleme dökmesi zorluklar içeriyor. Örneğin, öğrenciler " $e$ ” sesini öğrendikten sonra " $l$ " sesini öğrenmektedirler. İki sesten oluşan "el" kelimesini yazmak iki harfi birleştirmenin ötesinde bir çalışma 
gerektirmektedir” diyerek harfleri birleştirmenin yarattığı güçlükler üzerinde durmuştur.

Bitişik eğik yazı öğretiminde eksiklik olarak değerlendirilen bir diğer nokta veli desteğidir. Öğretmenler velilerin bitişik eğik yazı bilmediklerini bu nedenle öğrencilere çalışmalarında yardımda bulunamadıklarını belirtmektedirler. Ö1 bu konuda, "Veliler bitişik eğik yazıyı bilmedikleri için öğrencilere bu süreçte çok yardımcı olamıyorlar. Öğrencilerin zorlandıkları noktada veli desteğini alamıyoruz" diyerek veli desteğinin bu yazı biçiminde kullanılamadığını belirtmiştir.

\section{Sınıf Öğretmenlerinin Dik Temel Yazıya İlişkin Düşünceleri}

Sınıf öğretmenleri ile yapılan görüşmeler sonucunda sınıf öğretmenlerinin çoğunun dik temel yazı öğretimini olumlu olarak değerlendirdikleri görülmüştür. Öğretmenler (Ö9, Ö11) bu durumu, "Öğrencilerin yazısı okunur duruma geldi" şeklinde belirtmişlerdir. Bunun nedeni olarak öğrencilerin daha az yorulmalarını, sadece hatalı harfin silinmesini ve harflerin yazım yönlerinin kolay olmasını göstermişlerdir.

Öğretmenler dik temel yazı öğretiminin bitişik eğik yazıya göre daha kolay olduğunu belirtmişlerdir. Bunun nedenlerinden biri olarak harflerin yazım şekillerinin kolay olması gösterilmektedir. Öğretmenler özellikle anasınıfı eğitimi almamış öğrencilerin dik temel yazıyı daha rahat yazdıklarını belirtmişlerdir. Bir diğer neden olarak öğrencilerin bu harflere olan yatkınlığını göstermektedirler. Ö7, dik temel harflerin neden daha kolay öğretildiğini şu şekilde anlatmıştır: "Dik temel harfler hayatın her alanında kullanıldığından çocuk bu yazı ile çok karşılaşmaktadır. Böylece aşinalık kazanılıyor. Ayrıca harfleri günlük hayattan materyallere benzetebiliyoruz. E, tarak; O, simit; C Ay gibi”.

Yazmaya hazırlık çalışmaları için ayrılan süre bitişik eğik yazıya göre daha az tutulmuştur. Hem öğrenciler hem de öğretmenler yazma sürecini daha kısa zamanda ve zorlanmadan tamamlamışlardır. Ö15 bu konuda, "Öğrenciler temel çizgileri daha kolay yaptıkları için hazırlık çalışmaları kısa sürede tamamlanabiliyor" diyerek dik temel yazının yazma sürecini kısalttığını belirtmektedir.

Dik temel yazı genelde olumlu olarak değerlendirilmektedir. Öğretmenler olumsuz olarak öğrencilerin harfler arasındaki boşluğu ayarlayamamalarını belirtmişlerdir. Ö2 bu konuda, "Dik temel yazıda her harfi yazarken el kaldırılması harfler arasındaki bağlantıyı zorluyor. Harfler ayrı ayrı kalıyor” demiştir. Yazarken yapılan hataların yanı sıra harflerin yazım yönlerinde bazı yanlışların olduğu da vurgulanmıştır. Ö3, özellikle $d$ harfinin yazımı ile ilgili, "Yazı yazmada özellikle $d$ harfi yazılırken öğrenciler boşluğu tam olarak ayarlayamıyorlar. Öğrenciler önce $d$ harfinin çubuğunu çizip sonra yuvarlağını çiziyorlar. Aslında her zaman önce sol taraf yazılsa bu sorun ortadan kalkar” ifadesinde bulunmuştur. Öğretmenler bazı harflerin yazımında fazladan el hareketleri yapıldığını vurgulamaktadır. Örneğin $n$ harfi yazılırken el kaldırılarak iki hamlede yazılmaktadır. Ö3 bu durumu, "Bazı harflerin yazımı öğrencilerin birden fazla el hareketi yapmasına neden oluyor. Örneğin $n$ harfi 
iki hamlede gösterilmiş. Ancak öğrenciler bunu tek hamlede yapabiliyorlar. Ben her iki şeklini de gösteriyorum. Öğrenci hangisini rahat yazarsa onu serbest bırakıyorum" şeklinde belirtmiştir. Ö8 bu durumu, harflerin yazılış yönü belirlenirken yazım kolaylığının göze alınmayışına bağlamıştır.

Dik temel yazıda ortaya çıkan bir diğer olumsuz durum ise bazı harflerin birbiri ile karıştırılmasıdır. Özellikle $b$ ve $d$ harfleri birbiri ile karıştırılmaktadır. Öğretmenlerin büyük bir bölümünün $b$ ve $d$ harfinin karıştırıldığına vurgu yaptı̆̆ görülmektedir. Bu karışıklığı gidermek için ise iki harfin farklı gruplarda yer alması gerektiği belirtilmiştir.

\section{Sınıf Öğretmenlerinin El Yazısı Biçiminin Okuma Sürecine Olan Etkisine Yönelik Düşünceleri}

Sınıf öğretmenlerine, yazı biçiminin okuma sürecinde bir etkisinin olup olmadığı sorulduğunda öğretmenlerden farklı cevaplar alındığı görülmüştür. Ö2, "Dik temel yazının öğrencilerin okuma başarılarını etkilediğini düşünüyorum. Dik temel yazı daha seri ve okunaklı. Okuma ve algılamayı da olumlu etkiliyor. Etkinlikler daha hizlı yapılıyor" diyerek dik temel yazıyı öğrenen öğrencilerin okumada daha başarılı olduğunu belirtmiş̧ir. Dik temel yazının okuma sürecini olumlu etkilemesinin bir nedeni olarak bu yazı biçiminin sıkça kullanılması gösterilmiştir. Ö10, "Kitaplarla uyumlu olmasının okuma sürecinde etkili olacağını düşünüyorum" diyerek öğrenilen harflerle kitaplarda ya da farklı yazılı materyallerde karşılaşılmasının okuma sürecini olumlu etkileyeceğini belirtmiş̧tir. Bunun yanı sıra bitişik eğik yazının okuma sürecini yavaşlattığını belirten ifadelere de rastlanmıştır. Ö12 bu konuda,"Harflerin bağlanma olayı gözlerin hızlı bir şekilde hecelerin üzerinden atlamasını geciktirmektedir" demektedir. Bu durum ögrencilerin okuma becerilerinin gelişmesini etkilemektedir.

Bunun yanında harflerin birleştirilmesi ve ses temelli cümle yöntemi birleştirildiğinde öğrencilerin hecelemede sorunlar yaşadığı ortaya konmaktadır. Ö4 bu durumu, "Atatürk yazarken öğrenciler bitişik eğik yazıda daha fazla heceliyorlar. Öğrenciler hecelemede zorlanıyorlar" şeklinde açıklamıştır. Ayrıca bitişik eğik yazının bazı durumlarda okumayı zorladığı belirtilmiştir. Örneğin şiir kelimesinde iki $i$ harfinin birleşmesi $\ddot{u}$ harfini andırmaktadır. Bu durum hem öğrencilerin harfleri tanıyamamasına hem de hecelemeyi tam yapamamalarına neden olacaktır. Özellikle birinci sınıfta yazılı metinlerle yeni tanışmaya başlayan öğrenciler için bu durum okumada zorlanmaya neden olabilir.

\section{Sınıf Öğretmenlerinin Bitişik Eğik Yazının Öğretilmesine İlişkin Görüşleri}

Bitişik eğik yazı ile okuma yazma öğretimi 2005-2017 yılları arasında Türkiye'de tartışılan önemli konulardan biri olmuştur. 2017 yllında dik temel yazının kullanılmaya geçilmesi bu süreçten sonra bitişik eğik yazının nasıl kullanılması gerekliliği ile ilgili öğretmen görüşlerini önemli duruma getirmiştir. Öğretmenlerle yapılan görüşmeler sonucunda bitişik eğik yazının kullanımı ile ilgili farklı görüşlere rastlanmıştır. Öğretmenlerin bir kısmı bitişik eğik yazının estetik yönüne vurgu yapmaktadırlar. Örneğin Ö7'nin,“Mutlaka çocuklara öğretilmesi fikrindeyim. Estetik 
anlayış, yazı ve düşüncede bütünlük ve akıcılık kazandırılması gibi avantajları mutlaka hayata geçirilmeli" diyerek bitişik eğik yazının hem estetik yönüne hem de düşüncenin hızlı biçimde yazıya geçirilmesindeki etkisine vurgu yaptığı görülmektedir. Ö11 ise, "Bitişik eğik yazı üçüncü sınıftan itibaren güzel yazı dersi başlığı altında öğretilebilir. Çocuklar bu sınıfta okuma ve yazma işlerini hallettikten sonra harfler sıra ile öğretilerek kolayca yazmaları sağlanabilir. Böylece kendi yazı karakterlerini oluşturabilirler" diyerek öğrencilerin kendi yazı karakterlerini oluşturabilmeleri için bitişik eğik yazının öğretilmesi gerektiğini belirtmiştir.

Bazı öğretmenler ise bitişik eğik yazının öğretilmesine gerek olmadığını vurgulamışlardır. Ö3 bu konuda, "Bence bitişik eğik yazı öğretilmemeli. Artık dijital çağa geçiyoruz. Mesela emoji öğretilmeli. Sosyal medyada emoji çok önemli. Bence ileride emoji kullanılacak. Herkes kendi stilini kendi oluşturmalı" diyerek artık yazı biçiminin de değişen çağa ayak uydurması gerektiğini belirtmiştir. Bir diğer öğretmen (Ö6) ise, "Öğrenmek zorunda mıyız? Zamanla benim yazı da el yazısı olmuş. Birçok harf birleşmiş zaten" diyerek düşüncenin yazıya aktarılması ile zamanla bireyin yazısının bitişik eğik yazıya benzeyeceğini belirtmiştir. Burada belirtilmeye çalışılan yazı yazıldıkça yazı biçiminin kendiliğinden oluşacağıdır. Ö14 ise, bitişik eğik yazı öğretilse bile öğrencilerin ortaokulda tekrar düz yazı kullanmaya başladıklarını belirtmiştir. Bu nedenle bitişik eğik yazı öğretimine gerek olmadığını belirtmektedir.

\section{Tartışma, Sonuç ve Öneriler}

Okuma-yazma öğretimi sürecinde kullanılan yazı biçimi, okuma-yazma sürecinin olumlu bir şekilde ilerlemesi için oldukça önemli bir konudur. Özellikle öğrenci düzeyine ve kullanılan dile uygun yazı biçimlerinin belirlenmesi, bu sürecin kolay biçimde sürdürülmesinde yardımcı olacaktır. Bu araştırmada hem bitişik eğik yazı ile hem de dik temel yazı ile okuma yazma öğretimi gerçekleştiren birinci sınıf öğretmenlerinin bu yazı biçimlerinin birinci sınıfta kullanımına ilişkin görüşlerinin ortaya çıkarılması amaçlanmıştır.

Sınıf öğretmenlerinin bitișik eğik yazının kullanımına ilişkin görüşleri incelendiğinde öğretmenlerin çoğunun olumsuz görüş bildirdiği görülmüştür. $\mathrm{Bu}$ durum alanyazında yapılan bazı çalışmalar ile benzerlik göstermektedir. Arslan ve Ilgın (2010), Ateş, Çetinkaya ve Yıldırım (2014), Kırmızı ve Kasap (2013), Yıldırım ve Ateş (2010), Yılmaz ve Cimbız (2016) tarafından yapılan çalışmalarda sınıf öğretmenlerinin çoğunun bitişik eğik yazı öğretimini uygun bulmadıkları belirlenmiştir. Yine öğretmen adaylarıyla (Erdem, Yılmaz ve Bozkurt, 2014), öğrencilerle (Palavan ve Gemalmaz, 2017), velilerle (Coşkun ve Coşkun, 2014) yapılan çalışmalarda da bitişik eğik yazının öğrenciler için uygun olmadığı ortaya konmuştur.

Sınıf öğretmenlerinin bitişik eğik yazıyı uygun bulmama nedenlerinden biri öğrencilerin el kaslarının gelişmemiş olmasıdır. Öğrencilerin el kasları gelişmediği için öğrenciler el kaldırmadan yazmaları gereken kelimeleri yazmakta zorlanmakta ve bunun sonucunda yazmaya karşı olumsuz tutum geliştirmektedirler. Arslan (2012), 
Bayat (2014), Yıldırım ve Ateş (2010) tarafından yapılan çalışmalarda da öğretmenlerin, öğrencilerin el kaslarının bitişik eğik yazı yazmaya uygun olmadığını belirttikleri görülmektedir. Arslan'ın (2012) yaptığı çalışmada bir öğretmenin, “İlk başta küçük kaslar gelişmediği için zorlandılar, sağa yatırmada zorlanıyorlar. Dik yazmak istiyorlar" diyerek bu araştırmayı destekler ifadeler kullandığına rastlanmaktadır. Çevik tarafından (2006) belirtilen "Çocuklar parmak kasları açısından ileri ve geri ters yönde çevirmelerde oldukça sıkıntı çektiler" (s. 71) ifadesi de bu araştırmayı destekler niteliktedir. Yine Yılmaz ve Cımbız (2016) tarafindan yapılan çalışmada belirtilen "Öğrencinin fiziksel gücü özellikle uzun sözcükleri yazarken yeterli olmuyor” (s. 579) ifadesi öğrencilerin kas gelişiminin yetersiz olduğunun bir göstergesi niteliğindedir. Kırmızı ve Kasap (2013), el kasları gelişen öğrencilerin yazılarının güzel olduğunu, gelişmeyen öğrencilerin yazılarının ise okunmadığını belirtmiştir. Yıldız ve diğ. (2015), öğrencilerin okul öncesi dönemdeki yazı şekillerinin dik temel yazıya uygun olduğunu belirtmektedir. Bu nedenle bitişik eğik yazı yazarken öğrenciler zorlanmaktadırlar. Bu zorlanmanın ise öğrencileri psikolojik olarak olumsuz etkilediği bu araştırmada bazı öğretmenler tarafindan vurgulanmıştır.

Bitişik eğik yazının uygun bulunmamasının nedenlerinden bir diğeri bu yazı biçimi ile günlük yaşamda çok fazla karşılaşılmamasıdır. Çocuk eline ilk kalemi aldığından itibaren doğrusal çizgiler çizmekte ve bunları birleştirerek ilk harflerini oluşturmaktadır (Yıldız ve diğ., 2015). Yine kitaplarında, televizyonda ya da diğer görsel iletişim araçlarında dik temel yazı ile karşılaşmaktadır. Bu ön yaşantılar ile okula gelen öğrenciler bitişik eğik yazı yazmakta zorlanmaktadırlar. Bu süreç ise öğrencinin ortaokula geçmesi ile sona ermekte, öğrenci ortaokul ile birlikte dik temel yazı yazmaya başlamaktadır (Yıldız, 2019). Palavan ve Gemalmaz (2017), bitişik eğik yazının üçüncü sınıftan sonra bırakılmaya başlandığını, Yıldız (2019) ise dördüncü sınıftan sekizinci sınıfa kadar bitişik eğik yazı kullanma oranının azaldığını ortaya koymuştur. Bulut, Kuşdemir ve Şahin (2016), öğrencilerin yazı tercihlerinin ilkokuldan ortaokula geçişte değiştiğini belirtmektedir. Buna göre öğrenciler ortaokula geldiklerinde branş derslerinin etkisiyle dik temel yazı kullanmaya başlamaktadırlar (Bulut, Kuşdemir ve Şahin, 2016). Ancak ilkokulda, ortaokuldan farklı olarak sınıf öğretmenleri bitişik eğik yazının üzerinde oldukça durmaktadırlar. Öğrencilerde dik temel yazı yazma isteği görülse bile öğretmenler tarafindan engellenerek programa uygun yazmaları sağlanmaktadır. Ancak ortaokulda böyle bir zorlama ile karşılaşmayan öğrenci dik temel yazı kullanmaya başlamaktadır.

Veli desteği ilkokul birinci sınıflar için çok önemlidir. Bilinçli ve bilgili veli çocuğunun gelişmesine olumlu katkılarda bulunmaktadır. Ancak bitişik eğik yazı ile ilgili sınırlı bilgi sahibi olan ya da hiç bilgiye sahip olmayan veliler bu süreçte çocuklarına yardımcı olamadıkları gibi bazı durumlarda onların öğrenmelerini olumsuz etkileyebilmektedirler. Bu araştırmada bitişik eğik yazı öğretiminde veli desteğinin tam olarak alınamadığı öğretmenler tarafından belirtilmiştir. Araştırmayı destekler nitelikte Bayat (2014), Coşkun ve Coşkun (2014), Çevik (2006) ve Korkmaz 
(2006) velilerin bitişik eğik yazıyı bilmediklerini ve bunun sonucunda da yanlış öğretme eğiliminde olduklarını ortaya koymuşlardır.

Sınıf öğretmenleri, bitişik eğik yazının bazı olumsuz özellikler içerdiğini vurgulamışlardır. Yazıların okunamaması, harflerin nokta ve yatay çizgilerini koyarken yapılan geri dönüşler, harflerin birbirine benzemesiyle okumada zorluklara neden olması, harflerin birbiri ile birleştirilmesinin ayrıca bir zorluk içermesi gibi nedenler bunlardan bazılarıdır. Yapılan araştırmalarda da bitişik eğik yazının bazı olumsuz özellikleri ortaya konulmaktadır. Yazarken eğikliğin korunamamas1, harflerin büyüklüklerinin ayarlanamaması ve okunaklı yazamama bu sorunlardan bazılarıdır (Bayraktar, 2006; Kadığlu, 2012; Turan ve Akpınar, 2008).

Araştırmada ortaya çıkan bulgulardan biri bitişik eğik yazı öğretiminin okurken bazı sorunlara neden olduğudur. Öğretmenlerin çoğu yazı biçiminin okuma sürecinde etkili olmadığını düşünürken bazı öğretmenler bu harflerin birbirine bağlanmalarının gözlerin heceler üzerinde atlamalarını zorlaştırdığını belirtmektedir. $\mathrm{Bu}$ duruma bitişik eğik yazıyı okurken öğrencilerin harfleri birbirine bağlama üzerinde yoğunlaşmaları neden olabilir. Bu konuda Akyol ve Temur (2008) tarafindan yapılan çalışmada öğrencilerin tekrarlı okuma yaptıkları ortaya konmaktadır. Örnek olarak içinden kelimesinin okunurken önce $i$-çin, sonrasında için-den ve en sonunda içinden şeklinde okunduğunu göstermişlerdir. Korkmaz (2006) da ilkokuma-yazma öğretiminde öğrencilerin hecelemede zorlandıklarını ortaya koymaktadır. Kırmızı ve Kasap (2013), dik temel harflerle okuma becerisinin daha çabuk kazandırılacağını belirtmiştir. Bunun nedeni olarak da harflere olan yatkınlığın okuma sürecini olumlu etkileyecek olmasını göstermiştir. Bitişik eğik yazıda harflerin birleşik yazılması ve birbirinden ayırt edilmesinin dik temel yazıya göre zor olması ayrıca dik temel yazıya olan yatkınlık, okuma sürecinde dik temel yazının daha etkili olmasına neden olabilir.

Araştırmada birinci sınıfta dik temel yazı kullanımı, sınıf öğretmenleri tarafindan olumlu olarak değerlendirilmiştir. Öğretmenler öğrencilerin yazılarının bitişik eğik yazıya göre daha okunur olduğunu belirtmişlerdir. Ayrıca harflerin yazımının kolay olması yazmaya hazırlık çalışmalarının ve harflerin yazımının kısa sürede tamamlanmasını sağlamıştır. Harflerin şekillerinin basit olması ve günlük hayattan objelere benzemesi harflerin yazımında kolaylık sağlamıştır. Dik temel yazının bu olumlu özellikleri alanyazında yapılan çalışmalar ile benzerlik göstermektedir (Çakır, Aslantaş ve Arslan, 2018; Kırmızı ve Kasap, 2013).

Dik temel yazının bazı olumsuz yönlerinin de olduğu vurgulanmaktadır. Bunlardan bir kısmı dik temel yazıya özgü olan ve alanyazında sıklıkla vurgulanan harfler arası boşluk, harflerin boylarının eşit olmaması gibi olumsuz yönlerdir (Duran ve Akyol, 2010; Şahin, 2012). Bunun yanında Türkçe programındaki uygulamadan kaynaklanan eksikliklerin olduğu da vurgulanmıştır. Öğretmenler harflerin programdaki yazım yönlerinin öğrenciyi zorlayabileceğini belirtmişlerdir. Özellikle küçük $d$ harfinin önce çubuğunun çizilip sonra yuvarlağının çizilmesi bu harfin önündeki harf ile sıkışmasına neden olmaktadır. Yine $n$ ve $m$ gibi harflerin yazımında elin kaldırılmasının fazladan hareket yapılmasına yol açtığı belirtilmiştir. Bu durumun 
ise harflerin gözden geçirilerek yazım kolaylığına göre düzenlenmesi ile ortadan kaldırılabileceği belirtilmiştir.

Bitişik eğik yazıdan dik temel yazıya geçişte karşılaşılan bir sorun da bazı harflerin birbiri ile çok fazla karıştııılmasıdır. Özellikle $b$ ve $d$ harfleri birbiri ile çok karıştırılmaktadır. Güneş (2017), dik temel yazıda kullanılan simetrik harflerin birbiri ile karıştırılabileceğini belirtmektedir. Bazı öğretmenlerin (Ö3, Ö8, Ö10 ve Ö11) "Bitişik eğik yazıda $b$ ve $d$ harfleri bu kadar karıştırılmıyordu" demeleri burada dik temel yazının bu karışıklı̆ı ortaya çıkarmada etkili olabileceği sonucunu ortaya çıkarmaktadır. Dik temel yazıda her harf kendine özgü ve kendi içinde de farklılaşan çizgiler içermektedir. Bitişik eğik yazıda ise harfin tamamı bir bütün olarak yazılmaktadır. Bu durum harflerin bütün olarak algılanarak karıştırılmasının önüne geçebilir. Alanyazına bakıldığında özellikle $b$ ve $d$ seslerinin bitişik eğik yazıda da karıştırıldığı görülmektedir (Şahin, 2012). Bu karışıklığın önlenebilmesi için ise en azından harflerin farklı gruplar içinde öğretilmesi gerektiği vurgulanmıştır.

Öğretmenlerin üzerinde durduğu bir diğer nokta ise bitişik eğik yazının birinci sınıf dışında öğretilmesi ya da hiç öğretilmemesidir. Bazı öğretmenler bitişik eğik yazının özellikle öğrencinin estetik bir bakış geliştirmesine, zihnindeki düşünceleri hızlı ve akıcı bir şekilde yazıya aktarmasına yardımcı olduğu için öğretilmesi gerektiğini vurgularken bir kısmı dijital gelişmeler nedeni ile bitişik eğik yazının öğretilmesine gerek olmadığını belirtmiştir. Birinci sınıfta ise hem okuma öğretiminin hem de bitişik eğik yazı öğretiminin yapılmasının öğrenciyi zorladığı ifade edilmiştir. $\mathrm{Bu}$ nedenle bitişik eğik yazı öğretilecekse öğrencilerin okuma becerisini tam olarak kazanmalarından sonra öğretilmesi gerektiği belirtilmiştir. Öğrencilerin dördüncü sınıftan sonra kendi yazı karakterlerini oluşturmaya başladıkları belirtilmektedir. Yapılan çalışmalar ise hem bitişik eğik yazı hem dik temel yazı öğrenen öğrencilerin daha hızlı yazdıklarını ortaya koymaktadır (Graham ve diğ., 1998). Graham, ve diğ. (1998) bu durumu iki yazı biçimini de öğrenen öğrencilerin harfleri kendi oluşturdukları bir düzende yazarak kendi biçimlerini oluşturmalarına bağlamaktadır. Ouzoulias (2004) ise dik temel harfleri yazan kişilerin hızlı ve seri yazmak zorunda kaldıklarında dik harfleri birbirine bağladıklarını belirtmektedir. Böylece akıcı bir yazma gerçekleşmektedir. $\mathrm{Bu}$ durumlar öğrencilere kendi yazı karakterlerini oluşturabilmeleri ve akıcı bir şekilde yazabilmeleri için bitişik eğik yazının öğretilmesini gerekli kılabilir (akt. Güneş, 2017). Burada bitişik eğik yazının ne zaman öğretileceği ile ilgili tam bir görüş birliği olmasa da ikinci sınıfın ikinci döneminden sonra öğretilebileceği ile ilgili görüşlerin ortaya konduğu görülmektedir. Bu görüş Kırmızı ve Kasap (2013) ile benzerlik göstermektedir.

Dijital gelişmelerin yoğun olduğu bu yüzyılda yazı öğretimi ile ilgili ayrıntılı analizlerin yapılması gerekmektedir. Geçmişte güzel yazı yazmak bir saygınlık belirtisi iken günümüzde yazma işlevi çoğunlukla dijital araçlarla yapılmaktadır. Günlük yaşamda birey çok nadiren el yazısı kullanmaktadır. Bu durum öğretmenlerin düşüncelerini de etkilemiştir. Araştırmada bir öğretmenin (Ö3) emoji öğretiminden söz etmesi, diğer bir öğretmenin (Ö1) üç yaşındaki çocuğundan örnek vererek 
“yazmak yerine akıllı telefona konuşarak istediği yazıyı yazdırıyor” demesi, farklı bir çağda olduğumuzun göstergesi niteliğindedir. Bu değişim sözlü tarihten yazılı tarihe geçişimizden bu yana yaşadığımız en önemli değişimlerden biridir (Kellner, 2002). Dünya bütünüyle teknoloji ile donatılırken insan becerilerinin de teknolojiye uyumlu bir şekilde geliştirilmesi gerekmektedir. Amerika Birleşik Devletleri'ne bakıldığında bazı eyaletlerde yazma çalışmalarının tabletler üzerinden yürütüldüğü görülmektedir (Güneş, 2017). 21. yüzyılda dijital teknolojilerde meydana gelen gelişmeler dik ve bitişik eğik yazıya bakışı değiştirmektedir. Artık öğretmenler yazı öğretimine daha az zaman harcamaktadırlar. Öğretmenler el yerine dijital araçlarla yazma becerilerinin geliştirilmesi yönünde desteklenmektedirler (Supon, 2009). Bu durum yazı ve yazma araçları ile ilgili ayrıntılı ve geleceğe yönelik çalışmaların yapılmasını gerektirmektedir. Özellikle klavye, bitişik eğik yazı ve dik temel yazı kullanımının öğrencilerin yazılı anlatım becerilerini nasıl etkilediğini ortaya koyacak çalışmalara gereksinim duyulmaktadır. Bu çalışmaların uzamsal nitelikte olması ve birkaç yıl devam etmesi yazı biçimlerinin etkiliği hakkında ayrıntılı bilgi sahibi olunmasını sağlayacaktır. İleriye dönük uzun dönemli bu önerilerin yanı sıra kısa vadede dik temel harflerin öğrenimini kolaylaştırmak için harflerin ses gruplarındaki yerlerinin değiştirilmesi ve harflerin yazım yönlerinde bazı değişikliklerin yapılması önerilmektedir. Öğrencilerin sıklıkla karıştırdıkları $b-d$, $l-n$ gibi harflerin birbirinden farklı gruplarda olması yerinde olacaktır. Ayrıca yazımı çok kolay olan harflerin bile örneğin $n, m, p$ gibi en az iki hamlede yazılması, gereksiz yere elin kaldırılmasına neden olmaktadır. Bundan dolayı harflerin yazım yönleri tekrar incelenerek yazı akıcılığını sağlayacak biçimde Türkçe öğretim programında gerekli düzenlemelerin yapılması önerilmektedir.

Bitişik eğik yazı Latin harflerinin kabulünden bu yana programların bir parçası olagelmiştir. Atatürk, yeni alfabenin öğretiminde bitişik eğik yazıyı kullanmıştır. Sonraki süreçte bitişik eğik yazı öğretimi belli derslerde gerçekleştirilmiştir. 2005 yılından 2017 yılına kadar geçen sürede de birinci sınıftan itibaren bitişik eğik yazı öğretimi yapılmıştır. Günümüzde bir çok ülkede bitişik eğik yazı öğretilmektedir. Ancak Türkiye'de yapılan uygulamada bazı sorunlarla karşılaşılmıştır. Okul öncesi eğitimi almayan çocukların hazırbulunuşluk düzeylerinin düşük olması, ilkokuldan ortaokula geçişte bitişik eğik yazıya devam edilmemesi, branş öğretmenlerinin bu yazı biçimini kullanmamaları ve bu konuda eğitim almamaları, çevrede bu yazı biçiminde yazılarla karşılaşılmaması sorunlardan bazılarıdır. Sözedilen sorunları gidermeden bitişik eğik yazı öğretiminden istenilen verimi almak zor olacaktır. Bu araştırmadan çıkan sonuçlar doğrultusunda bitişik eğik yazı öğretiminin okuma-yazma öğrenildikten sonra yapılması, yazı kullanımına bütün öğretim düzeylerinde dikkat edilmesi, öğretmenlerin gerekli eğitimleri almalarının sağlanması önerilmektedir. Araştırmacılara yönelik olarak yazı biçimlerinin etkilerinin ortaya konulabilmesi için dik temel yazı ve bitişik eğik yazı ile okuma-yazma öğrenmiş öğrenciler üzerinde yeni araştırmaların yapılması önerilmektedir. 


\section{Kaynakça}

Akyol, H. (2005). Yeni programa uygun Türkçe ilkokuma-yazma öğretimi. Ankara: Pegem Akademi.

Akyol, H. ve Temur, T. (2008). Ses temelli cümle yöntemi ve cümle yöntemi ile okuma-yazma öğrenen öğrencilerin okuma becerilerinin öğretmen görüşlerine göre değerlendirilmesi. Mustafa Kemal Üniversitesi Sosyal Bilimler Enstitüsü Dergisi, 5(9), 79-95.

Arastaman, G., Fidan, İ. Ö. ve Fidan, T. (2018). Nitel araştırmada geçerlik ve güvenirlik: Kuramsal bir inceleme. YYÜ Eğitim Fakültesi Dergisi, 15(1), 37-75.

Arslan, D. (2012). İlköğretim birinci sınıf öğretmenlerinin yazı öğretimlerinin incelenmesi. Kuram ve Uygulamada Eğitim Bilimleri, 12(4), 2829-2846.

Arslan, D. ve Ilgın, H. (2010). Öğretmen ve öğrencilerin bitişik eğik yazı ile ilgili görüşleri. Inönü Üniversitesi Eğitim Fakültesi Dergisi, 11(2).

Ateş, S., Çetinkaya, Ç. ve Yıldırım, K. (2014). Sınıf öğretmenlerinin yazma güçlükleri hakkındaki görüşleri. International Online Journal of Educational Sciences, 6(2), 475-493.

Bara, F., and Morin, M. F. (2013). Does the handwriting style learned in first grade determine the style used in the fourth and fifth grades and influence handwriting speed and quality? A comparison between French and Quebec children. Psychology in the Schools, 50(6), 601-617.

Başkale, H. (2016). Nitel araştırmalarda geçerlik, güvenirlik ve örneklem büyüklüğünün belirlenmesi. Dokuz Eylül Üniversitesi Hemşirelik Fakültesi Elektronik Dergisi, 9(1), 23-28.

Bayat, S. (2014). Sınıf öğretmenlerinin ilkokuma yazma programının uygulanmasında karşılaştıkları güçlüklere ilişkin görüşleri. Illköğretim Online, 13(3), 759-775.

Bayraktar, Ö. (2006). Illköğretim birinci sınıf öğrencilerinin bitişik ĕgik yazıda yaptıkları hatalar (Yayımlanmamış yüksek lisans tezi). Gazi Üniversitesi Eğitim Bilimleri Enstitüsü, Ankara.

Berninger, V. W., Abbott, R. D., Jones, J., Wolf, B. J., Gould, L., Anderson, M., ..., Apel, K. (2006). Early development of language by hand: Composing, reading, listening, and speaking connections; three letter-writing modes; and fast mapping in spelling. Developmental Neuropsychology, 29, 61-92.

Bulut, P., Kuşdemir, Y. ve Şahin, D. (2016). İlkokul ve ortaokulda yazı tercihi: Öğrenci ve öğretmenler hangi yazı türünü kullanıyor? Mustafa Kemal Üniversitesi Sosyal Bilimler Enstitüsü Dergisi, 13(34), 98-115. 
Christensen, C. A. (2005). The role of orthographic-motor integration in the production of creative and well-structured written text for students in secondary school. Educational Psychology, 25(5), 441-453.

Coşkun, E. ve Coşkun, H. (2012). İlköğretim öğrencileri ile sınıf ve Türkçe öğretmenlerinin bitişik eğik yazı başarı düzeylerinin değerlendirilmesi. Gazi University Journal of Gazi Educational Faculty (GUJGEF), 32(3), 761-776.

Coşkun, E. ve Coşkun, H. (2014). İlkokul ve ortaokullardaki bitişik eğik yazı uygulamalarına ilişkin öğretmen, öğrenci ve veli görüşleri. Mustafa Kemal Üniversitesi Sosyal Bilimler Enstitüsü Dergisi, 11(26), 209-223.

Creswell, J. W. (2016). Nitel araştırma yöntemleri: Beş yaklaşıma göre nitel araştırma ve araştırma deseni [Qualitative inquiry and research design: choosing among five approaches]. (M. Bütün ve S. B. Demir, Çev.). Ankara: Siyasal Kitabevi (Orijinal kitabın yayın tarihi 2013).

Çakır, O., Arslan, G. A. ve Doğan, M. C. (2018). İlkokul öğretmenlerinin bitişik eğik yazı ve dik temel harflerin kullanımına ilişkin görüşlerinin değerlendirilmesi. Kastamonu Ĕgitim Dergisi, 26(5), 1539-1550.

Çelenk, S. (2007). İlkokuma-yazma programı ve ögrretimi. Ankara: Maya Akademi.

Çevik, S. (2006). Birinci sınıf öğretmenlerinin ilkokuma yazma ögrretiminde ses temelli cümle yöntemine ilişkin görüşleri (Bursa ili örneği) (Yayımlanmamış yüksek lisans tezi). Anadolu Üniversitesi Eğitim Bilimleri Enstitüsü, Eskişehir.

Durukan, E. ve Alver, M. (2008). Ses temelli cümle yönteminin öğretmen görüşlerine göre değerlendirilmesi. The Journal of International Social Research, 1(5), 274289.

Duran, E. ve Akyol, H. (2010). Bitişik eğik yazı öğretimi çalışmalarının çeşitli değişkenler açısından incelenmesi. Türk Ĕgitim Bilimleri Dergisi, 8(4), 817-838.

Prince Edward Island Department of Education and Early Childhood Development Holman Centre (2012). Guidelines for handwriting instruction: Printing and cursive, kindergarten to grade 6 . Retrieved from http://www.gov.pe.ca/photos/original/eecd_printcurk6.pdf

Erdem, İ., Yılmaz, F. ve Bozkurt, E. (2014). Sınıf öğretmeni adaylarının bitişik eğik yazıya ilişkin tutumları. Inönü Üniversitesi Eğitim Fakültesi Dergisi, 15(1), 1 26.

Gates, A. I., and Brown, H. (1929). Experimental comparisons of print-script and cursive writing. The Journal of Educational Research, 20(1), 1-14.

Graham, S. (2010). Want to improve children's writing? American Educator, 33(4), 20-40. 
Graham, S., and Weintraub, N. (1996). A review of handwriting research: Progress and prospects from 1980 to 1994. Educational psychology review, 8(1), 7-87.

Graham, S., Weintraub, N., and Berninger, V. W. (1998). The relationship between handwriting style and speed and legibility. The Journal of Educational Research, 91(5), 290-297.

Güneş, F. (2007). Ses temelli cümle yöntemi ve zihinsel yapılandırma: ses bilinci, yazı bilinci, zihinsel sözlük, beyin teknolojisi, anlama modelleri. Ankara: Nobel.

Güneş, F. (2017). Bitişik eğik ve dik temel yazı savaşları. Sınırsız Eğitim ve Araştırma Dergisi, 2(3), 1-20.

Kadığlu, H. (2012). Bitişik eğik yazıya ilişkin öğrenci görüşleri, Akademik Bakış Dergisi, 31, 1-10.

Kellner, D. (2002). New media and new literacies: Reconstructing education for the new millenium [Yeni teknolojiler/yeni okur-yazarlıklar: Yeni bin yılda eğitimin yeniden yapılandırılması]. Kuram ve Uygulamada Eğitim Bilimleri, 2(1), 105132.

Kırmızı, F. S. ve Kasap, D. (2013). İlkokula yazma öğretimi sürecinde bitişik eğik yazı ve dik temel harflerle yapılan eğitimin öğretmen görüşlerine göre karşılaştırılması. Electronic Turkish Studies, 8(8), 1167-1186.

Korkmaz, İ. (2006). Yeni ilköğretim birinci sınıf programının öğretmenler tarafından değerlendirilmesi. Selçuk Üniversitesi Sosyal Bilimler Enstitüsü Dergisi, (16), 419-431.

Lincoln, Y. S., and Guba, E. G. (1985). Naturalistic inquiry (Vol. 75). Baverly Hills, CA: Sage.

Milli Eğitim Bakanlı̆̆ http://mufredat.meb.gov.tr/Dosyalar/201812312239736-

T\%C3\%BCrk\%C3\%A7e\%20\%C3\%96\%C4\%9Fretim\%20Program\%C4\%B1

\%202018.pdf adresinden elde edilmiştir.

Meulenbroek, R. G., and van Galen, G. (1990). Perceptual-motor complexity of printed and cursive letters. Journal of Experimental Education, 58, 95-110.

Morin, M. F., Lavoie, N., and Montésinos-Gelet, I. (2012). The effects of manuscript, cursive or manuscript/cursive styles on writing development in Grade 2. Language and literacy, 14(1), 110-124.

Palavan, Ö. ve Gemalmaz, N. (2017). Eğik el yazısıyla okuma yazma öğrenen öğrencilerin, eğik el yazısına ilişkin durumları. Ana Dili Eğitimi Dergisi, 5(4), 589-608. 
Patton, M. Q. (2014). Nitel araştırma ve değerlendirme yöntemleri [Qualitative Research \& Evaluation Methods](M. Bütün ve S. B. Demir, Çev.). Ankara: Pegem Akademi (Orijinal kitabın yayın tarihi 2001).

Sharp, L., and Brown, T. (2015). Handwriting instruction: An analysis of perspectives from three elementary teachers. Texas Journal of Literacy Education, 3(1), 2937.

Supon, V. (2009). Cursive writing: Are its last days approaching? Journal of Instructional Psychology, 36(4), 357-359.

Şahin, A. (2012). Bitişik eğik yazı öğretiminde karşılaşılan problemler. Eğitim ve Bilim, 37(165), 168-179.

Turan, M. ve Akpınar, B. (2008). İlköğretim Türkçe dersi ilkokuma-yazma öğretiminde kullanılan ses temelli cümle ve bitişik eğik yazı yöntemlerinin değerlendirilmesi. Firat Üniversitesi Sosyal Bilimler Dergisi, 18(1), 121-138.

Yıldırım, A. ve Şimşek, H. (2013). Sosyal bilimlerde nitel araştırma yöntemleri (9. Genişletilmiş Baskı). Ankara: Seçkin.

Ylldırım, K. (2010). Raising the quality in qualitative research. Illkogretim Online, 9(1), 79-92.

Yıldırım, K. ve Ateş, S. (2010). Sınıf öğretmenlerinin bitişik eğik yazı öğretim uygulamalarına ilişkin görüşleri. Pamukkale Üniversitesi Sosyal Bilimler Enstitüsü Dergisi, (5), 57-71.

Yıldiz, M. (2019). Cursive handwriting reform and its aftermath in Turkey: Which handwriting style do primary school (4th-8th Grades) students use? Egitim ve Bilim, 44(197), 209-222.

Yıldız, M., Ataş, M., Aktaş, N., Yekeler, A. D. ve Dönmez, T. (2015). Çocuklar ne yazıyor? Okul öncesi dönemde yazı algısının gelişimi. Turkish Studies, 10(3), 1131-1152.

Yılmaz, F. ve Cımbız, A. T. (2016). Sınıf öğretmenlerinin bitişik eğik yazı hakkındaki görüşleri. Yüzüncü Yll Üniversitesi Eğitim Fakültesi Dergisi, 13(1), 567-592.

Yurduseven, S. (2007). Illkokuma yazma programının öğretmen görüşleri çerçevesinde değerlendirilmesi (Yayımlanmamış yüksek lisans tezi). Afyon Kocatepe Üniversitesi Sosyal Bilimler Enstitüsü, Afyon. 


\title{
First Grade Teachers' Views About Teaching Writing
}

Style

\begin{tabular}{cccc}
\hline $\begin{array}{c}\text { ARTICLE TYPE } \\
\text { Research Article }\end{array}$ & $\begin{array}{c}\text { Received Date } \\
12.04 .2018\end{array}$ & $\begin{array}{c}\text { Accepted Date } \\
04.29 .2019\end{array}$ & $\begin{array}{c}\text { Published Date } \\
04.29 .2019\end{array}$ \\
\hline & Yusuf Özdemir iD ${ }^{1}$ & \\
Ministry of National Education & \\
Kasım Kıroğlu iD ${ }^{2}$ & \\
Ondokuz Mayıs University
\end{tabular}

\begin{abstract}
The cursive handwriting, which started teaching in the 2005-2006 academic year, has left its place to the script handwriting with the academic year of 2017-2018. It was seen that the cursive handwriting was criticized in many respects during the time it was used. Factors such as unreadable writings of students, not continue use of cursive handwriting after primary school, low number of written text in this style in current life have been criticized aspects of cursive handwriting. In this study, it's aimed to compare the views of first grade classroom teachers who have taught cursive handwriting in first grade and teaching script handwriting in the 2017 - 2018 academic year, about two writing style. For this purpose, interviews were conducted with classroom teachers in Alaçam district of Samsun province. The sample of the study consisted of all first grade teachers who had also done cursive handwriting instruction. The case study which is a qualitative research method was used in the research. The research data were collected by a semi-structured interview form which was developed by the researchers. Descriptive analysis was performed on the obtained data. As a result of the research, teachers stated that it is not appropriate to teach cursive handwriting in the first grade. Teachers satisfy positively the instruction of script handwriting. However, there are some problems related to the spelling and the groups of the letters. In the teaching of cursivehandwriting, they stated that they encountered problems in terms of readiness, use of writing in secondary school and exposure to writing.
\end{abstract}

Keywords: Language skills, writing, writing instruction, cursive handwriting, script handwriting.

${ }^{1}$ Corresponding Author: Dr., Sehit Muhammet Ali Aksu Primary School, E-mail: yusuefozdemir@hotmail.com, https://orcid.org/ 0000-0003-2024-6916

${ }^{2}$ Associate Professor, Faculty of Education, Basic Education Department, E-mail: november@omu.edu.tr, https://orcid.org/0000-0001-5711-9182 


\section{Purpose and Significance}

In the literature, there are many studies on teaching of cursive handwriting and script handwriting. These studies started with the twentieth century on the abroad (e.g. Gates and Brown, 1929). In Turkey the studies showed an increase with the starting of cursive handwriting instruction in 2005. From this moment onwards, different results were found. In some studies, the use of cursive handwriting has been considered positive (Durukan and Alver, 2008; Turan and Akpınar, 2008) while in some studies it has been considered negative (Bayraktar, 2006; Kırmızı and Kasap, 2013; Yurduseven, 2007). The teaching of the cursive handwriting has ceased to be a necessity and the choice of writing style is left to the teachers in the 2017-2018 academic year. In this sense, it is very important to get the opinions of the teachers who have taught both cursive handwriting and script handwriting in order to clarify the situation regarding the teaching of both writing styles. Removing the necessity of cursive handwriting instruction and beginning to the teaching of script handwriting reveals an appropriate situation in order to clarify the views of teachers about both writing styles. The fact that teachers will present their thoughts about the writing styles in a comparative way reveals the importance of the research.

In the study it is aimed to give detailed information about teaching of the both writing styles in first grade. For this aim, the following problems were searched in the study.

1. What are the thoughts of the classroom teachers about the cursive handwriting?

2. What are the thoughts of the classroom teachers about the script handwriting?

3. What are the thoughts of the classroom teachers about the effect of handwriting fonts on the reading process?

4. What are the views of the classroom teachers on the teaching of cursive handwriting?

\section{Method}

The case study which is a qualitative research method was used in the study. The case study is defined as the investigation of a situation within the real life, the current context or the environment. A case study is a good approach when the researcher has clearly identifiable situations with their borders and tries to establish an in-depth understanding of the situation (Creswell, 2016). The study group of the research is consisted with the first grade classroom teachers who worked in Alaçam district of Samsun province in the 2017-2018 academic year. There are 16 teachers in the study group. All of these teachers had previously taught writing with cursive handwriting.

As a data collection tool, a semi-structured interview form developed by researchers was used. While some of the teachers in the study group were interviewed face to face, some of the answers were taken in writing. Then, descriptive analysis 
was performed on the data obtained. In order to ensure the validity and reliability of the research, it has been emphasized on the transferability, credibility, dependability, reliability. The term internal validity is similar to credibility; external validity is similar to transferability; the term reliability similar to dependability and objectivity is similar to confirmability (Creswell, 2016; Patton, 2014).

Descriptive analysis was performed on the data obtained from the study. The data obtained from descriptive analysis are summarized and interpreted according to predetermined themes (Yıldırım and Şimşek, 2013). The data obtained from this study were arranged according to the problems of the research. The data were grouped according to research problems and under each problem data were read and combined in a meaningful and logical manner.

\section{Results}

As a result of the study, the classroom teachers stated that the cursive handwriting instruction was not suitable in the first grade. The reasons that stated by teachers were hand muscles of the students are not developed, cursive handwriting is not encountered in real life and parents have not been informed about this writing style. In addition cursive writing is a aesthetic writing style. Conducting both handwriting and reading instruction together force the students. Teachers evaluate the use of script handwriting positively. They (T9, T11) stated that "The students handwriting is readable." about the script handwriting. They stated that preparatory works related to this script handwriting were completed in a short time and students were not forced to write letters. Students are familiar with these letters, so they adapt more quickly to the reading process. However, there are some problems in the use of these script handwriting letters. Firstly, some letters are mixed with each other. Especially the letters $b$ and $d$ are frequently mixed with each other. In addition, the spelling of some letters is seen as an obstacle for students to write. For example, the letters $m$ and $n$ are made in two moves. When writing $d$ letter firstly the line was drawn. This causes the letter to be jammed with the letter in front. Therefore, it was stated that changing the shapes of some letters and groups of letters would lead to ease of teaching the writing. Teachers have different views on the effect of writingstyles on the reading process. Some teachers stated that the reading process is not related to writing styles, it is related to the reading instruction method. But some of the teachers think that writing style is very effective in reading process. Because it will be easier to detect the letters they are familiar with. It is sometimes difficult to distinguish between letters in cursive handwriting. This adversely affects the reading process. There are different opinions of teachers about the teaching of the cursive handwriting. Some teachers stated that the cursive handwriting will be teaching after the first grade. Cursive handwriting is preferred because it provides aesthetical view and allows the person to create their own writing character. Some teachers said there was no need to teach cursive handwriting. Because the world is going to the digital age. 


\section{Discussion and Conclusions}

When we look at the opinions of classroom teachers on the use of cursive handwriting, it was seen that most of the teachers reported negative opinions. This situation is similar to some studies in the literature. The studies done by Arslan and Ilgın (2010), Ateş, Çetinkaya and Yıldırım (2014), Kırmızı and Kasap (2013), Yıldırım and Ateş (2010), Yılmaz and Cımbız (2016), found that most of the classroom teachers did not approve the cursive handwriting instruction. Again, the studies done with teacher candidates (Erdem, Y1lmaz and Bozkurt, 2014), students (Palavan and Gemalmaz, 2017) and parents (Coşkun and Coşkun, 2014) were showed same results. One of the reasons why classroom teachers do not agree with the cursive handwriting is that the hand muscles are not developed. Students were forced to write without raising hands. Arslan (2012), Bayat (2014), Yıldırım and Ateş (2010) also founds same results about weak hand muscles. Kirmız and Kasap (2013) state that if students hand muscles were strong they wrote beautiful. But if not, their writings were illegible. Cursive handwriting rarely use in daily life. Students are not often faced with cursive handwriting in books, magazines and in the media. Therefore, the students have been forced. The other reason about forced in cursive is insufficient parents support. Supporting to this research, Bayat (2014), Coşkun and Coşkun (2014), Çevik (2006) and Korkmaz (2006) showed that parents do not know the cursive handwriting and consequently tend to mislead.

In the study, the use of script handwriting in the first grade was evaluated positively by the classroom teachers. Teachers stated that students' writings were more readable than the cursive handwriting. Easy writing of letters provided the complete preparative works and writing letters at the short time. Both the simplicity shapes and similarity to real life objects had provided easy writing of the letters. These positive characteristics of script handwriting are similar with results of the studies in the literature (Çakır, Aslantaş and Arslan, 2018; Kırmızı and Kasap, 2013). It was emphasized that there are some negative aspects of script handwriting. Some of these are the space between letters and the unequal size of the letters which were emphasized in the literature frequently (Duran and Akyol, 2010; Şahin, 2012). In addition, it is emphasized that there are deficiencies in the Turkish Curriculum. Teachers stated that the writing shapes of the letters in the curriculum could force the student. Especially firstly drawing the stick and then drawing the circle causes to squeezing the letter $d$ with the letter in front of it. It was also stated that the removal of the hand caused some extra movement in the writing of some letters such as $n, m$. It is said that this situation can be eliminated by revising the letters according to the ease of writing. Teachers also stated that the letters $b$ and $d$ were mixed a lot. Güneş (2017) states that symmetrical letters used in the script handwriting can be mixed with each other. In order to prevent this confusion, it was emphasized that letters should be taught in different groups.

Another point that teachers focus on is that the cursive handwriting is taught outside of the first class or not taught at all. Some teachers emphasized that 
handwriting should be taught because it helps the student to develop an aesthetic view and to transfer the thoughts in his mind quickly and fluently. But it is stated that the cursive handwriting should be taught after the students acquire the reading skill in fully. Some teachers stated that there is no need to teach cursive handwriting due to digital developments. The studies revealed that students who learned both cursive and script handwriting wrote faster (Graham, Weintraub and Berninger 1998). This may require the teaching of cursive handwriting in order for students to be able to create their own typefaces and to write fluently (Güneş, 2017). Therefore, handwriting can be taught after the second semester of the second year. This view is similar with Kirmizi and Kasap (2013).

Now, most of people use digital communication tools. They use emoji for communication sometimes. And there are technologies that convert sound to writing. This change is one of the most important changes that we have experienced since the transition from oral history to writing history (Kellner, 2002). This situation requires detailed and future studies related to writing and writing tools. 